\title{
An investigation into the normality of the distributions of financial ratios of listed South African industrial companies
}

\author{
A.C. Jordaan, E. v.d. M. Smit \& W.D. Hamman* \\ University of Stellenbosch Business School, P.O. Box 610, Bellville 7535, Republic of South Africa
}

Received August 1993, accepled November 1993

\begin{abstract}
In this article we examine some of the inter-temporal and cross-sectional distributional properties of a selected number of financial ratios of South African industrial companies and we evaluate the effect of a simple procedure of outlier rejection. The normality assumption is rejected consistently in the case of the industry analysis and frequently in the
\end{abstract} sectoral and yearly analyses.

In dié artikel word sommige van die intertemporale en deursnee verdelingseienskappe van 'n geselekteerde aantal finansiële verhoudings van Suid-Afrikaanse nywerheidsmaatskappye onlleed en die resultaat van 'n eenvoudige metode van uitskieterverwydering word geëvalueer. Die normaliteitsaannames word konsekwent op industriële vlak en dikwels op sektorale en jaarvlak verwerp.

*Author to whom correspondence should be addressed at P.O. Box 1009, Bellville 7535.

\section{Introduction}

Financial ratios are used for various purposes, such as corporate failure prediction, bond rating, security analysis, commercial credit rating, the estimation of accounting-based measures of risk and the investigation into differences in accounting practices by different companies (Ezzamel, Brodie \& Mar-Molinero, 1987). Most of these applications employ parametric statistical procedures of which the validity partly depends on the underlying distributional properties of the ratios. Barnes (1987: 451) and Foster (1986: 101-102) stress the importance of knowledge about the distributional properties of financial ratios. First, it is required in order to use the ratios themselves in controlling for the effect of size on the financial variables under analysis or to control for industry-wide factors. A financial institution, for example, before lending money, may wish to determine where on the industry distribution a loan applicant's ratio falls or a corporation may wish to determine the upside potential of a decision to move a particular financial ratio of a business unit into the ninth industry decile. In financial research knowledge of distributions may lead to more optimal decisions of sample size in studies aimed at estimating the financial characteristics of a population. Second, closely connected to the first argument, an examination of the distributions will indicate whether the ratio distribution can be characterized by only two parameters, the mean and standard deviation, as is practise when a normal distribution is assumed. Should the normal distribution be used to estimate risk in a situation where the underlying distribution displays strong kurtosis, the use of the standard deviation may lead to serious underestimation of the risk involved. Third, a number of statistical techniques used in financial analysis assume multivariate normality. Such models, however, are sensitive to the presence of skewed data. For example, standard discriminant analysis procedures assume that the variables used to describe or characterize the members of the different groups are multivariate normally distributed. Violation of this assumption may bias tests of significance and the estimated error rates (Eisenbeis, 1977). In regression analysis the distribution of the variables affect the assumption of errors that are NID $\left(0, \sigma^{2}\right)$. If the assumption is violated, it prevents an assessment of the statistical reliability of the coefficient estimates using the classical $t$ - or $F$ tests. An examination of the distributional patterns of financial ratios will caution against the injudicious application of these models. In the fourth place, evidence on distributional properties may provide a stimulus to subsequent research which may promote better understanding of the empirical regularities and/or imegularities in financial statement data.

It is clear from the above arguments that the normal distribution plays an important role in financial statement analysis. However, despite the attractions of working with the normal distribution, reasons exist for expecting non-normality in a number of ratios. Barnes (1982) has shown that asymmetry will result from lack of proportionality between the numerator and denominator in a financial ratio. Some financial ratios have technical limits (e.g. a lower limit of zero and/or an upper limit of $100 \%$ ) which will prevent literal normality, or economic limits may result in fewer tailend observations that would be expected under the normal.

This article is aimed at investigating the normality assumption for the financial ratios of listed South African industrial companies over the period 1970 to 1992. The remainder of this article is organized as follows. A second section contains a brief summary of a literature survey while in a third section the research method is oullined. A fourth section contains the results and a final section the conclusions.

\section{Literature survey}

Internationally a substantial amount of research has been done to determine whether the distributions of financial ratios conform to the normality assumption. In general it has been found that few ratios are normally distributed. Further attempts have been made to evaluate normality after the data were screened for outliers (extreme values) and also after the data have been transformed using logarithmic, square root and cubic adjustments in an effort to obtain normality. 
Further issues such as the impact of year-end dates and sample sizes have also been investigated.

In an early study of the United States manufacturing sector Horrigan (1965) reported distributions which tended to be approximately normal, but with some evidence of positive skewness. In contrast, Deakin (1976) concluded that in the United States manufacturing sector, out of eleven ratios tested, ten were significantly different from a normal distribution and that only the total debt/total assets ratio was normally distributed.

In testing for the normality of financial ratios in Australia, Bird \& McHugh (1977) concluded that financial leverage and efficiency ratios were generally normally distributed, but that ratios related to quick assets and asset structure in general were not. A study on the distributional properties of financial ratios in the United Kingdom conducted in 1976 by Bougen \& Drury (1980) indicated that the ratios tended not to be normally distributed. Frecka \& Hopwood (1983), in investigating United States manufacturing companies from 1950 to 1979 , found that in most cases, when outliers were removed from distributions close to normal, normality was achieved. However, in the case of raw data, normality was rejected. Buijink \& Jegers (1986), in a Belgian study over the period 1977 to 1981 , could not conclusively accept or reject normality. So (1987) also rejected, for United States companies, the assumption of normality.

Ezzamel, Mar-Molinero \& Beecher (1987) argued that three common observations had emerged from the literature. First, all studies pointed towards positive skewness in the distributions of the ratios. This might be attributed to an effective lower limit of zero, but an indefinite upper limit for most ratios. Second, those ratios which considerably departed from normality, were characterized by the presence of extreme outliers. Third, they observed that raw data transformation tended to improve approximations to normality, but did not solve the outlier problem. In a subsequent article Ezzamel \& Mar-Molinero (1990) could not find support for the assumption of normality in the distributions of nine financial ratios examined for United Kingdom data.

In a recent preliminary South African study, using the same nine ratios as Ezzamel \& Mar-Molinero (1990), Muil, Hamman \& Smit (1992) concluded that as regards skewness, industry ratios showed a tendency to be positively skewed in all but the case of the total debt/total assets ratio which was negatively skewed. These results carried through to the sectoral level. Conceming kurtosis, it was concluded that on both the industrial and sectoral level, outlier removal had a tendency to improve the standardized coefficients of kurtosis to within the typical normal range in most of the ratios examined. Very little evidence of normality could be found using the raw data set, but outlier rejection tended to improve the situation.

The current research is an extension of the previous work in so far as 27 ratios, rather than the initial nine ratios, are examined; the sample is differently constituted; and the time frame is extended to the period 1970 to 1992 compared to the 1980 to 1989 period which was utilized in the 1992 research.

\section{Research method}

The present study is conducted on 27 financial ratios (see Table 1) of listed South African industrial companies over

Table 1 Description of ratios

\begin{tabular}{|c|c|c|c|}
\hline $\begin{array}{l}\text { Ratio } \\
\text { number }\end{array}$ & Ratio description & Abbreviations & Bounds \\
\hline \multirow[t]{2}{*}{1} & Current assets/current liabi- & & \\
\hline & lities & CUR & 0 to $\infty$ \\
\hline \multirow[t]{2}{*}{2} & Current assets"100hotal & & \\
\hline & assets & CATA & 0 to 100 \\
\hline 3 & Stock*100hotal assets & STOCKתIA & 0 to 100 \\
\hline 4 & Debtors*100hotsl assets & $\mathrm{DEB} / \mathrm{TA}$ & 010100 \\
\hline \multirow[t]{2}{*}{5} & Current liabilities*100houal & & \\
\hline & assets & CL/TA & 0 to 100 \\
\hline 6 & Creditors*100/total assets & CRED/TA & 0 to 100 \\
\hline 7 & Stock*365/sales & STOCK365 & 0 to \\
\hline 8 & Debtors $* 365 /$ sales & DEB365 & 0 to $\infty$ \\
\hline 9 & Creditors*365/sales & CRD365 & 0 to $\infty$ \\
\hline 10 & Sales/total assets & SATA & Small to $\infty$ \\
\hline \multirow[t]{2}{*}{11} & Long-term debi* $100 /$ total & & \\
\hline & assets & LTD/TA & 0 to 100 \\
\hline 12 & Ordinary equity* $100 /$ total assets & EQ/TA & 0 to 100 \\
\hline \multirow[t]{2}{*}{13} & Interest bearing debt $* 100 /$ & & \\
\hline & total assets & IB/TA & 0 to 100 \\
\hline 14 & Total debt*100/hotal assets & TD/TA & 0 to 100 \\
\hline \multirow[t]{2}{*}{15} & (Total debt+prefs)*100hotal & & \\
\hline & assets & DP/TA & 0 to 100 \\
\hline \multirow[t]{2}{*}{16} & Ordinary equity* 100 hong- & & \\
\hline & term debt & EQ/LTD & Unbounded \\
\hline \multirow[t]{2}{*}{17} & Long-term debt* $100 /$ ordinary & & \\
\hline & equity & LTD/EQ & 0 to $\infty$ \\
\hline \multirow[t]{2}{*}{18} & Toual deba $* 100$ /ordinary & & \\
\hline & equity & $\mathrm{D} / \mathrm{E}$ & Unbounded \\
\hline \multirow[t]{2}{*}{19} & Ordinary equity* 100 houal & & \\
\hline & debt & E/D & Unbounded \\
\hline \multirow[t]{2}{*}{20} & EBIT/interest paid (interest & & \\
\hline & cover) & IC & Unbounded \\
\hline 21 & Dividend cover & DC & Unbounded \\
\hline \multirow[t]{2}{*}{22} & Profit before taxation ${ }^{*} 100 /$ & & \\
\hline & sales & PBT/SA & Unbounded \\
\hline \multirow[t]{2}{*}{23} & Profit after taxation $* 100 /$ & & \\
\hline & sales & PATSA & Unbounded \\
\hline \multirow[t]{2}{*}{24} & Profit after taxation $* 100$ hotal & & \\
\hline & assets & PAT/TA & Unbounded \\
\hline 25 & EBIT*100/total assets & EBIT/TA & Unbounded \\
\hline 26 & Retum on equity & ROE & Unbounded \\
\hline 27 & EBIT*100/sales & EBIT/SA & Unbounded \\
\hline
\end{tabular}

Notes

Total assets $\quad=$ Fixed assets (excluding intangible assets) + other assets + current assets

Total debe $=$ Long-term debt (excluding deferred taxation) + current liabilities

Equity = Shareholders' interest (excluding intangible assets)

Prefs = Preference share capital

EBIT = Profit before taxation + interest paid

ROE $\quad=$ (Profit after taxation - preference dividends minority interest in profits) $* 100 /$ Equity 
the period 1970 to 1992 . The chosen ratios cover six major ratio analysis components namely liquidity (one ratio), working capital composition (five ratios), activity (four ratios), debt (nine ratios), coverage (two ratios), and profitability (six ratios).

The raw financial data from the listed companies' annual reports were extracted from the University of Stellenbosch Business School Data Base and transformed into the financial ratios for each company for each year. To be included in the sample a company must have published a 1991 annual report and still have been listed at the end of 1992. Only those companies for which 1992 reports were available at the time of analysis were included in the study in respect of 1992. For each company included in the study the ratios pertaining to the first year of inclusion were deleted, because it could not be ascertained from the data base whether the results pertained to a full financial year. Also all investment holding companies and pyramid companies, of which the sole or main asset is an investment(s) in other listed South African companies, were deleted to preclude possible a-

- typical pattems in the financial ratios. Non-South African companies were also deleted on the assumption that they may operate in different types of markets.

Next, extreme values were considered. The approach used was to delete outliers beyond three standard deviations from the mean. No judgement was exercised in removing outliers.

This approach is contrary to Buijink \& Jegers' (1986: 343) referral to Bougen \& Drury's (1980) use of judgement and their view that removing outliers beyond three standard deviations was contrary to the fundamental proof of normality being sought, since the outliers would directly impact on the normality test. This critique was heeded and both the raw data and data after outlier removal were tested for normality. The present approach is also contrary to that of Ezzamel \& Mar-Molinero (1990) who used the three standard deviation procedure, but also exercised judgement in rejecting outliers.

The current approach was used because a high premium was placed on objectivity in handling the data. The resulting sample sizes before and after outlier rejection are shown in Table 2. The key to the sector codes can be found in the Appendix.

The analysis of the data is done on three levels:

- all data are combined and the assumption of normality

for each of the ratios tested over all sectors and over all time periods (referred to as the industry level);

- the ratios for the full period are divided into sectors and the results in the respective sectors are aggregated over time (the sectoral level); and

- the ratios are analyzed per year while aggregated over sectors (the yearly level).

Insufficient observations precluded the analysis of the ratios per sector per year.

Finally the results are tabulated and presented as the percentage of ratio distributions where the assumption of normality could not be rejected. This makes the results comparable to the international evidence cited above.

The statistical analysis relies heavily on the computation
Table 2 Average sample sizes

\begin{tabular}{|c|c|c|c|}
\hline & & Raw dae & $\begin{array}{l}\text { After outlier } \\
\text { rejection }\end{array}$ \\
\hline (a) Incustry & & 3203 & 3167 \\
\hline \multicolumn{4}{|l|}{ (b) Sectors } \\
\hline & 15 & 509 & 503 \\
\hline & 21 & 98 & 96 \\
\hline & 22 & 260 & 257 \\
\hline & 23 & 88 & 87 \\
\hline & 24 & 286 & 283 \\
\hline & 25 & 160 & 157 \\
\hline & 26 & 68 & 67 \\
\hline & 27 & 137 & 135 \\
\hline & 28 & 263 & 260 \\
\hline & 29 & 282 & 279 \\
\hline & 30 & 149 & 147 \\
\hline & 31 & 186 & 184 \\
\hline & 32 & 74 & 74 \\
\hline & 33 & 82 & 81 \\
\hline & 34 & 29 & 29 \\
\hline & 35 & 66 & 65 \\
\hline & 36 & 311 & 308 \\
\hline & 37 & 43 & 43 \\
\hline & 38 & 54 & 53 \\
\hline & 39 & 59 & 59 \\
\hline \multicolumn{4}{|l|}{ (c) Years } \\
\hline & 1970 & 37 & 36 \\
\hline & 1971 & 90 & 89 \\
\hline & 1972 & 95 & 94 \\
\hline & 1973 & 105 & 104 \\
\hline & 1974 & 106 & 105 \\
\hline & 1975 & 108 & 107 \\
\hline & 1976 & 111 & 109 \\
\hline & 1977 & 111 & 109 \\
\hline & 1978 & 112 & 111 \\
\hline & 1979 & 114 & 112 \\
\hline & 1980 & 120 & 118 \\
\hline & 1981 & 117 & 116 \\
\hline & 1982 & 129 & 127 \\
\hline & 1983 & 131 & 129 \\
\hline & 1984 & 129 & 127 \\
\hline & 1985 & 131 & 129 \\
\hline & 1986 & 135 & 133 \\
\hline & 1987 & 147 & 144 \\
\hline & 1988 & 191 & 188 \\
\hline & 1989 & 259 & 256 \\
\hline & 1990 & 281 & 278 \\
\hline & 1991 & 288 & 285 \\
\hline & 1992 & 156 & 154 \\
\hline
\end{tabular}

of standardized coefficients of skewness and kurtosis and batteries of tests for normality. Standardized coefficients of skewness and kurtosis are used as descriptive measures. A standardized coefficient of skewness or kurtosis outside the range -2 to +2 indicates significant departure from a normal distribution. Two tests are used to test for normality, namely the chi-square goodness-of-fit test and the Kolmogorov- 
Smimov (K-S) test. The Kolmogorov-Smimov test is preferred over the chi-square test if the sample size is small. While there is controversy over which test is more powerful, the general feeling seems to be that the K-S test is probably more powerful than the chi-square test in most situations (Conover, 1971: 295). This conclusion, however, is not

Table 3a Statistical summary: industry level

(a) Raw dasa

\begin{tabular}{|c|c|c|c|c|c|c|c|c|c|c|}
\hline \multirow{3}{*}{$\begin{array}{l}\text { Calegory } \\
\text { Ratio } \\
\text { Mean }\end{array}$} & \multirow{3}{*}{$\begin{array}{r}\text { Liquidity } \\
\text { CUR } \\
1.88\end{array}$} & \multirow{3}{*}{$\frac{\text { CA/TA }}{60.81}$} & \multicolumn{4}{|c|}{ Working capital composition } & \multicolumn{4}{|c|}{ Aclivity } \\
\hline & & & \multirow{2}{*}{$\frac{\text { STOCK/TA }}{26.58}$} & \multicolumn{3}{|c|}{ DEB/TACL/TA CRED/TA } & \multirow{2}{*}{$\frac{\text { STOCK365 }}{61.84}$} & \multirow{2}{*}{$\begin{array}{r}\text { DEB365 } \\
71.18\end{array}$} & \multicolumn{2}{|c|}{ CRD365SA/TA } \\
\hline & & & & 27.49 & 38.71 & 23.38 & & & 56.75 & 1.71 \\
\hline Median & 1.57 & 61.99 & 26.11 & 25.95 & 37.29 & 20.97 & 58.65 & 63.25 & 52.21 & 1.54 \\
\hline Mode & 1.47 & 54.40 & 0.00 & 0.00 & 36.45 & 19.44 & 0.00 & 59.56 & 55.46 & 1.61 \\
\hline Sundard deviation & 4.11 & 20.54 & 15.59 & 15.80 & 16.77 & 13.54 & 37.21 & 58.73 & 29.35 & 1.01 \\
\hline Minimum & 0.01 & 0.18 & 0.00 & 0.00 & 0.21 & 0.03 & 0.00 & 0.00 & 1.00 & 0.10 \\
\hline Maximum & 221.00 & 99.87 & 87.88 & 94.56 & 196.25 & 112.19 & 520.06 & 926.73 & 453.07 & 12.36 \\
\hline Sundardized skewness & 1092.49 & -11.83 & 8.19 & 24.54 & 18.75 & 26.23 & 47.31 & 105.99 & 76.93 & 52.20 \\
\hline Standardized kurtosis & 2866.69 & -2.23 & -1485.00 & 22.10 & 37.86 & 23.53 & 190.72 & 457.48 & 339.92 & 119.69 \\
\hline P-value (chi-square) & 0.00 & 0.00 & 0.00 & 0.00 & 0.00 & 0.00 & 0.00 & 0.00 & 0.00 & 0.00 \\
\hline P-value (K-S) & 0.00 & 0.00 & 0.00 & 0.00 & 0.00 & 0.00 & 0.00 & 0.00 & 0.00 & 0.00 \\
\hline
\end{tabular}

Table 3b Statistical summary: industry level

(a) Raw data

\begin{tabular}{lrrrrrrrrrr}
\hline Category & \multicolumn{10}{c}{ Deb } \\
\hline Ratio & LTD/TA & EQ/TA & IB/TA & TD/TA & DP/TA & EQ/LTD & LTD/EQ & D/E & E/D \\
\hline Mean & 10.05 & 44.20 & 20.08 & 48.67 & 50.17 & 2244.67 & 57.68 & 222.04 & 163.92 \\
Median & 7.87 & 43.43 & 18.82 & 48.84 & 50.24 & 361.14 & 18.41 & 113.50 & 87.03 \\
Mode & 0.00 & 42.06 & 0.00 & 50.47 & 45.92 & 0.00 & 0.00 & 86.31 & 115.86 \\
Standard deviation & 9.99 & 19.40 & 14.73 & 18.19 & 18.99 & 12577.36 & 1627.38 & 4596.59 & 855.80 \\
Minimum & 0.00 & -188.51 & 0.00 & 0.21 & 0.21 & -2042.20 & -5018.75 & -67135.71 & -254.15 \\
Maximum & 86.94 & 99.79 & 164.70 & 201.23 & 288.31 & 304697.22 & 94380.00 & 253669.38 & 47200.00 \\
Standardized skewness & 43.22 & -22.35 & 32.77 & 15.68 & 32.96 & 361.77 & 1368.86 & 1163.64 & 1173.76 \\
Standardized kunosis & 74.65 & 120.57 & 76.10 & 61.29 & 149.97 & 3395.34 & 39687.00 & 32695.41 & 32095.94 \\
P-value (chi-square) & 0.00 & 0.00 & 0.00 & 0.00 & 0.00 & 0.00 & 0.00 & 0.00 & 0.00 \\
P-value (K-S) & 0.00 & 0.00 & 0.00 & 0.00 & 0.00 & 0.00 & 0.00 & 0.00 & 0.00 \\
\hline
\end{tabular}

Table 3c Statistical summary: industry level

(a) Raw data

\begin{tabular}{lrrrrrrrr}
\hline Category & \multicolumn{1}{c}{ Coverage } \\
\hline Ratio & IC & DC & PBT/SA & PAT/SA & PAT/TA EBIT/TA & ROE EBIT/SA \\
\hline Mean & 38.63 & 2.61 & 9.63 & 6.21 & 8.05 & 15.64 & 10.45 & 11.88 \\
Median & 5.56 & 2.42 & 8.05 & 5.19 & 7.88 & 14.73 & 16.79 & 10.24 \\
Mode & 0.00 & 0.00 & 8.84 & 3.99 & 6.21 & 13.79 & 15.34 & 8.11 \\
Standard deviation & 243.81 & 3.75 & 9.85 & 7.39 & 8.75 & 10.87 & 685.89 & 10.01 \\
Minimum & -60.00 & -58.81 & -82.39 & -81.38 & -147.56 & -144.82 & -36298.30 & -63.43 \\
Maximum & 5675.00 & 82.22 & 114.23 & 111.88 & 123.04 & 144.09 & 14832.14 & 144.80 \\
Standardized skewness & 329.26 & 109.80 & 35.31 & 38.36 & -21.96 & 29.90 & -972.97 & 62.01 \\
Standardized kurtosis & 279.55 & 2059.16 & 180.73 & 400.24 & 1069.45 & 548.51 & 28392.60 & 306.40 \\
P-value (chi-squarc) & 0.00 & 0.00 & 0.00 & 0.00 & 0.00 & 0.00 & DOF & 0.00 \\
P-value (K-S) & 0.00 & 0.00 & 0.00 & 0.00 & 0.00 & 0.00 & 0.00 & 0.00 \\
\hline
\end{tabular}

Note: DOF $=$ insufficient degrees of freedom 
borne out by the current research.

\section{Results}

The statistical results at industry level are presented in Table 3. Using both the chi-square test and the Kolmogorov-Smir- nov test, the null hypothesis of normality is rejected in all cases at the $2 \%$ level of significance (and even lower levels). Financial ratios, aggregated over time and over sectors, are clearly not normally distributed, both before and after outlier removal.

Table 3d Statistical summary: industry level

(b) After outlier removal

\begin{tabular}{lrrrrrrrrrrr}
\hline Category & Liquidity & \multicolumn{4}{c}{ Working capital composition } & \multicolumn{3}{c}{ Activity } \\
\hline Ratio & CUR & CA/TA & STOCK/TA & DEB/TA & CL/TA CRED/TA & STOCK365 & DEB365 & CRD365 & SATTA \\
\hline Mean & 1.76 & 60.81 & 26.31 & 26.38 & 38.43 & 22.73 & 60.00 & 64.37 & 54.89 & 1.61 \\
Median & 1.57 & 61.99 & 25.99 & 25.67 & 37.22 & 20.77 & 58.27 & 62.63 & 51.90 & 1.53 \\
Mode & 1.47 & 54.40 & 0.00 & 0.00 & 36.45 & 19.44 & 0.00 & 59.56 & 55.46 & 1.61 \\
Standard deviation & 1.00 & 20.54 & 15.16 & 13.89 & 16.07 & 12.38 & 31.50 & 34.37 & 22.65 & 0.78 \\
Minimum & 0.01 & 0.18 & 0.00 & 0.00 & 0.21 & 0.03 & 0.00 & 0.00 & 1.00 & 0.10 \\
Maximum & 13.24 & 99.87 & 70.20 & 74.33 & 88.26 & 63.80 & 168.34 & 244.24 & 144.38 & 4.73 \\
Standardized skewness & 11.72 & -11.83 & 4.90 & 12.88 & 8.73 & 17.58 & 7.08 & 29.55 & 16.63 & 25.12 \\
Standardized kurtosis & 399.36 & -2.23 & -5.11 & 5.34 & 0.37 & 54.46 & 1.06 & 47.45 & 10.37 & 22.87 \\
P-value (chi-square) & 0.00 & 0.00 & 0.00 & 0.00 & 0.00 & 0.00 & 0.00 & 0.00 & 0.00 & 0.00 \\
P-value (K-S) & 0.00 & 0.00 & 0.00 & 0.00 & 0.00 & 0.00 & 0.01 & 0.00 & 0.00 & 0.00 \\
\hline
\end{tabular}

Table 3e Statistical summary: industry level

(b) After outlier removal

\begin{tabular}{lrrrrrrrrrr}
\hline Category & \multicolumn{10}{c}{ Deb } \\
\hline Ratio & LTD/TA & EQ/TA & IB/TA & TD/TA & DP/TA & EQ/LTD & LTD/EQ & D/E & E/D \\
\hline Mean & 9.45 & 44.68 & 19.48 & 48.35 & 49.61 & 1249.63 & 31.23 & 153.33 & 143.44 \\
Median & 7.70 & 43.54 & 18.72 & 48.82 & 50.02 & 357.63 & 18.41 & 113.49 & 86.77 \\
Mode & 0.00 & 42.06 & 0.00 & 50.47 & 45.92 & 0.00 & 0.00 & 86.31 & 115.86 \\
Standard deviation & 8.59 & 17.78 & 13.27 & 16.95 & 17.08 & 3270.94 & 68.91 & 364.42 & 227.00 \\
Minimum & 0.00 & -11.94 & 0.00 & 0.21 & 0.21 & -2042.20 & -648.58 & -6145.83 & -254.15 \\
Maximum & 39.62 & 99.79 & 63.67 & 101.65 & 104.51 & 39964.24 & 1382.67 & 12512.58 & 2565.66 \\
Standardized skewness & 22.28 & 7.59 & 11.57 & -4.28 & -1.80 & 144.00 & 187.45 & 285.02 & 138.10 \\
Standardized kurtosis & 4.61 & 1.53 & -2.92 & 0.47 & 1.01 & 551.56 & 1447.58 & 5394.35 & 509.99 \\
P-value (chi-square) & 0.00 & 0.00 & 0.00 & 0.00 & 0.00 & 0.00 & 0.00 & 0.00 & 0.00 \\
P-value (K-S) & 0.00 & 0.00 & 0.00 & 0.01 & 0.00 & 0.00 & 0.00 & 0.00 & 0.00 \\
\hline
\end{tabular}

Table $3 f$ Statistical summary: industry level

(b) After outlier removal

\begin{tabular}{lrrrrrrrr}
\hline Category & \multicolumn{1}{c}{ Coverage } & \multicolumn{7}{c}{ Profitability } \\
\hline Ratio & IC & DC & PBT/SA & PAT/SA & PAT/TA & EBIT/TA & ROE EBIT/SA \\
\hline Mean & 18.34 & 2.48 & 9.80 & 5.89 & 8.05 & 15.29 & 17.72 & 11.26 \\
Median & 5.53 & 2.41 & 8.32 & 5.15 & 7.88 & 14.68 & 16.79 & 10.15 \\
Mode & 0.00 & 0.00 & 8.84 & 3.99 & 6.21 & 13.79 & 15.34 & 8.11 \\
Standard deviation & 57.78 & 1.58 & 6.71 & 5.12 & 5.50 & 7.56 & 35.72 & 7.27 \\
Minimum & -60.00 & -8.27 & -0.17 & -13.21 & -17.46 & -16.32 & -902.29 & -14.95 \\
Maximum & 765.67 & 13.41 & 39.03 & 28.30 & 34.14 & 46.92 & 610.68 & 40.69 \\
Standardized skewness & 180.45 & 18.84 & 27.20 & 17.00 & 1.38 & 6.75 & -97.92 & 19.79 \\
Standardized kurtosis & 820.31 & 73.36 & 23.37 & 31.29 & 31.56 & 15.57 & 2433.56 & 21.70 \\
P-value (chi-square) & 0.00 & 0.00 & 0.00 & 0.00 & 0.00 & 0.00 & 0.00 & 0.00 \\
P-value (K-S) & 0.00 & 0.00 & 0.00 & 0.00 & 0.00 & 0.00 & 0.00 & 0.00 \\
\hline
\end{tabular}


The majority of ratios, in raw data format, tend to be positively skewed. The exceptions are the CA/TA, EQ/TA, PAT/TA and ROE ratios. After removal of the outliers EQ/TA and PAT/TA also become positively skewed, but TD/TA and DP/TA tend towards negative symmetry. Standardized kurtosis coefficients tend to be positive, indicating heavier tails than can be expected under a normal assumption. Outlier removal alleviates this problem to a certain degree. However, a similar effect on skewness is not noticeable.

The lack of normality may be explained, amongst others, by non-homogeneities introduced via the aggregation of sectors and/or time. To investigate the effect of sectors, the data were disaggregated and the tests applied to each sector after aggregation over time. The percentages of the sectors where normality could not be rejected at the $5 \%$ level of significance are presented in Table 4 . If one uses the chisquare test as norm, the percentages where normality could not be rejected, vary from $0 \%$ in the case of interest cover to $45 \%$ in the cases of the CL/TA and SA/TA ratios. Using the Kolmogorov-Smimov test, these percentages vary between $0 \%$ in the case of interest cover $1080 \%$ in the case of the CL/TA and the DP/TA ratio. Outlier removal is beneficial to normality as most of the percentages increase. In not a single instance could IC and EQ/LTD be shown to be normally distributed, while the CL/TA, SA/TA, PBT/SA, PAT/TA, EBIT/TA and EBIT/SA will less frequently violate the assumption of normality when analysis takes place on sectoral level. The overall conclusion, however, is clear. aggregating ratios over sectors has the effect of introducing non-homogeneities which mitigate against normality in the ratio distributions of the aggregated data.

To investigate the effect of aggregation over time, the data were disaggregated and the tests applied per year after aggregation over sectors. The percentages of the years when normality could not be rejected at the $5 \%$ level of significance are presented in Table 5. Here the evidence of normality is much stronger than it had been in the case of a sectoral breakdown. If one uses the chi-square test as norm, the percentages where normality could not be rejected, vary from $0 \%$ in the case of CUR, LTD/TA, EQ/LTD, LTD/EQ, $\mathrm{D} / \mathrm{E}, \mathrm{E} / \mathrm{D}, \mathrm{IC}, \mathrm{PAT} / \mathrm{SA}$ and ROE to $87 \%$ in the case of the CL/TA ratio. Using the Kolmogorov-Smimov test, these percentages vary between $0 \%$ in the case of CUR, EQ/LTD, LTD/EQ, D/E, E/D and IC to $100 \%$ for the STOCK/TA and CL/TA ratios. As before outlier removal is beneficial to normality. Also, as before, EQ/LTD and IC could not be shown to be normally distributed.

Table 5 Percentage of years where normality is not rejected $(\alpha=0.05)$

is not rejected $(\alpha=0.05)$

\begin{tabular}{|c|c|c|c|c|c|}
\hline \multirow{2}{*}{$\begin{array}{l}\text { Ratio } \\
\text { No }\end{array}$} & \multirow{2}{*}{$\begin{array}{c}\text { Ratio } \\
\text { Abbreviations }\end{array}$} & \multicolumn{2}{|c|}{ Raw data } & \multicolumn{2}{|c|}{ Outliers removed } \\
\hline & & Chi-square & $\mathrm{K}-\mathrm{S}$ & Chi-square & $\mathbf{K}-\mathbf{S}$ \\
\hline 1 & CUR & 20 & 35 & 25 & 55 \\
\hline 2 & CA/TA & 20 & 65 & 15 & 70 \\
\hline 3 & STOCK/TA & 15 & 60 & 15 & 65 \\
\hline 4 & DEB/TA & 15.8 & 55 & 30 & 55 \\
\hline 5 & CLTA & 45 & 80 & 50 & 85 \\
\hline 6 & CRED/TA & 30 & 50 & 25 & 55 \\
\hline 7 & STOCK 365 & 20 & 45 & 25 & 55 \\
\hline 8 & DEB365 & 15 & 50 & 25 & 65 \\
\hline 9 & CRED365 & 25 & 70 & 45 & 80 \\
\hline 10 & SA/TA & 45 & 65 & 50 & 70 \\
\hline 11 & LTD/TA & 5 & 35 & 15 & 45 \\
\hline 12 & EQ/TA & 15 & 70 & 25 & 75 \\
\hline 13 & $\mathrm{IB} / \mathrm{TA}$ & 35 & 65 & 40 & 75 \\
\hline 14 & TD/TA & 20 & 75 & 30 & 85 \\
\hline 15 & DP/TA & 25 & 80 & 40 & 90 \\
\hline 16 & EQ/LTD & 0 & 0 & 0 & 0 \\
\hline 17 & LTD/EQ & 5 & 15 & 5 & 20 \\
\hline 18 & $\mathrm{D} / \mathrm{E}$ & 10 & 25 & 20 & 40 \\
\hline 19 & E/D & 0 & 10 & 0 & 30 \\
\hline 20 & IC & 0 & $\mathbf{0}$ & 0 & 0 \\
\hline 21 & $\mathrm{DC}$ & 15 & 25 & 20 & 45 \\
\hline 22 & PBT/SA & 25 & 65 & 50 & 75 \\
\hline 23 & PATSA & 15.8 & 40 & 31.6 & 75 \\
\hline 24 & PAT/TA & 20 & 35 & 47.4 & 95 \\
\hline 25 & EBIT/TA & 36.8 & 60 & 60 & 95 \\
\hline 26 & ROE & 10 & 20 & 30 & 40 \\
\hline 27 & EBIT/SA & 15.8 & 55 & 40 & 75 \\
\hline
\end{tabular}

\begin{tabular}{|c|c|c|c|c|c|}
\hline \multirow{2}{*}{$\begin{array}{l}\text { Ratio } \\
\text { No }\end{array}$} & \multirow{2}{*}{$\begin{array}{c}\text { Ratio } \\
\text { Abbreviations }\end{array}$} & \multicolumn{2}{|c|}{ Raw data } & \multicolumn{2}{|c|}{ Outliers removed } \\
\hline & & Chi-square & K-S & Chi-square & K-S \\
\hline 1 & CUR & 0 & 0 & 8.7 & 43.5 \\
\hline 2 & CA/TA & 69.6 & 87 & 73.9 & 87 \\
\hline 3 & STOCK/TA & 65.2 & 100 & 60.9 & 100 \\
\hline 4 & $\mathrm{DEB} / \mathrm{TA}$ & 34.8 & 73.9 & 78.3 & 95.7 \\
\hline 5 & CLITA & 87 & 100 & 91.3 & 100 \\
\hline 6 & CRED/TA & 17.4 & 65.2 & 47.8 & 87 \\
\hline 7 & STOCK365 & 68.2 & 87 & 81.8 & 95.7 \\
\hline 8 & DEB365 & 4.5 & 8.7 & 31.8 & 47.8 \\
\hline 9 & CRED365 & 22.7 & 56.5 & 63.6 & 91.3 \\
\hline 10 & SAVTA & 8.7 & 26.1 & 34.8 & 47.8 \\
\hline 11 & LTD/TA & 0 & 34.8 & 0 & 56.5 \\
\hline 12 & EQ/TA & 73.9 & 95.7 & 82.6 & 100 \\
\hline 13 & IB/TA & 26.1 & 82.6 & 30.4 & 87 \\
\hline 14 & $\mathrm{TD} / \mathrm{TA}$ & 56.5 & 95.7 & 69.6 & 100 \\
\hline 15 & DP/TA & 73.9 & 95.7 & 87 & 100 \\
\hline 16 & EQ/LTD & 0 & 0 & 0 & 0 \\
\hline 17 & LTD/EQ & $\mathbf{0}$ & 0 & $\mathbf{0}$ & 17.4 \\
\hline 18 & $\mathrm{D} / \mathrm{E}$ & 0 & $\mathbf{0}$ & 0 & 34.8 \\
\hline 19 & $E / D$ & 0 & 0 & 0 & 4.3 \\
\hline 20 & IC & 0 & 0 & 0 & 0 \\
\hline 21 & DC & 8.7 & 13 & 17 & 47.8 \\
\hline 22 & PBT/SA & 4.5 & 34.8 & 31.8 & 82.6 \\
\hline 23 & PAT/SA & 0 & 26.1 & 30.4 & 78.3 \\
\hline 24 & PAT/TA & 13 & 43.5 & 56.5 & 91.3 \\
\hline 25 & EBIT/TA & 13 & 43.5 & 69.6 & 100 \\
\hline 26 & ROE & 0 & 8.7 & 47.8 & 56.5 \\
\hline 27 & EBIT/SA & 13 & 43.5 & 56.5 & 82.6 \\
\hline
\end{tabular}




\section{Summary and conclusion}

In this article we have sought to examine some of the intertemporal and cross-sectional distributional properties of financial ratios of South African industrial companies and to evaluate the effect of a simple procedure of outlier rejection namely removing data points further removed than three standard deviations from the mean.

The results of the tests revealed that the normality assumption was rejected consistently in the case of the industry analysis and frequently in the sectoral and yearly analyses. It was not possible to indicate conclusively whether this was due to the greater power of the test in the larger samples or because greater sample homogeneity improves approximation to normality. The extent of non-normality changed across sectors indicating possibly that sector specific characteristics impact on the properties of the distribution. The results of inter-temporal analysis suggest that normality is more often achieved when disaggregating over time.

If one has to advise a researcher or practitioner to whom ân underlying normal distribution in a financial ratio is important, one would probably advise in the first place to disaggregate over time, as a second approach to disaggregate over sectors, but never to treat the industry as a pooled sample. The results sound a warning to anyone injudiciously assuming normality in the distribution of financial ratios, whether it be in academic research or in accounting practice.

\section{References}

Barnes, P. 1982. 'Methodological implications of non-normally distributed financial ratios', Journal of Business Finance and Accounting, Vol. 9, No. 1: 51-62.

Barnes, P. 1987. 'The analysis and use of financial ratios: A review article', Journal of Business Finance and Accounting, Vol. 14, No. 4: 449-461.

Bird, R.G. \& McHugh, A.J. 1977. 'Financial ratios - an empirical study', Journal of Business Finance and Accounting. Vol. 4, No. 1: 29-44.

Bougen, P.D. \& Drury, J.C. 1980. 'UK statistical distributions of financial ratios, 1975', Journal of Business Finance and Accounting, Vol. 7, No. $1: 39-47$.

Buijink, W. \& Jegers, M. 1986. 'Cross-sectional distributional properties of financial ratios in Belgian manufacturing industries: aggregation effects and persistence over time', Journal of Business Finance and Accounting, Vol. 13, No. 3: 337-363.

Conover, W.J. 1971. Practical non-parametric statistics. New York: John Wiley and Sons Inc.

Deakin, E.B. 1976. 'Distributions of financial accounting ratios: some empirical evidence', The Accounting Review, January, pp. 90-96.

Eisenbeis, R.A. 1977. 'Pitfalls in the application of discriminant analysis in business, finance and economics', The Journal of Finance, Vol. 32, No. 3: 875-900.

Ezzamel, M., Brodie, J. \& Mar-Molinero, C. 1987. 'Financial patterns of UK manufacturing companies', Journal of Business Finance and Accounting, Vol. 14, No. 4: 519-536.

Ezzamel, M. \& Mar-Molinero, C. 1990. 'The distributional properties of financial ratios in UK manufacturing companies'. Journal of Business Finance and Accounting, Vol. 17, No. 1: 1-29.

Ezzamel, M., Mar-Molinero, C. \& Beecher, A. 1987. On the distributional properties of financial ratios', Jowrnal of Business Finance and Accounting, Vol. 14, No. 4: 463-481.

Foster, G. 1986. Financial statement analysis. Second Edition. Englewood Cliffs: Prentice-Hall.

Frecke, T.J. \& Hopwood. W.S. 1983. 'The effects of outliers on the cross-sectional distributional properties of financial ratios'. The Accounting Review, Vol. 63, No. 1: 115-128.

Horrigan, J.O. 1965. 'Some empirical bases of financial ratio analysis', The Accounting Review. July, pp.558-573.

Muil, W.R., Hamman, W.D. \& Smit, E. v.d. M. 1992. 'The distributional properties of some financial ratios of listed South African industrial companies: 1980-1989', De Ratione, Vol. 6, No. 2: 20-30.

So, J.C. 1987. 'Some empirical evidence on the outliers and the non-normal distribution of financial ratios'. Jowrnal of Business Finance and Accounting, Vol. 14, No. 4: 483-496.

Appendix: Sectors included in the analysis

Sector

code Sector description

\begin{tabular}{ll}
\hline 15 & Industrial holding \\
21 & Beverages, hotels and leisure \\
22 & Building and construction \\
23 & Chemicals and oils \\
24 & Clothing, footwear and textiles \\
25 & Food \\
26 & Fishing \\
27 & Fumiture and household goods \\
28 & Engineering \\
29 & Electronics, electrical and battery \\
30 & Motor \\
31 & Paper and packaging \\
32 & Pharmaceutical and medical \\
33 & Printing and publishing \\
34 & Steel and allied \\
35 & Transportation \\
36 & Retailers and wholesalers \\
37 & Sugar \\
38 & Development capital \\
39 & Tobacco and match \\
\hline
\end{tabular}

